\title{
QUALITY CONTROL OF HERBAL MEDICINES USED FOR ARTHRITIS: IDENTIFICATION AND QUANTIFICATION OF COX INHIBITORS BY HPLC, GC-MS, LC-MS-MS, GC-FID
}

\author{
NATHALIE MOUSSA ${ }^{1 *}$, AHMAD HASSAN $^{1}$, and ABDEL NASSER B. SINGAB ${ }^{2}$ \\ ${ }^{1}$ Department of Pharmaceutical Chemistry and Quality Control of Medicaments, \\ Faculty of Pharmacy, Damascus University, Damascus, Syria \\ ${ }^{2}$ Department of Pharmacognosy, Faculty of Pharmacy, Ain-Shams University, Cairo, Egypt
}

\begin{abstract}
The aim of the study was to challenge the common techniques utilized in the quality control of herbal products for the authentication of the two selected polyherbal products. Two polyherbal formulations, Voltarit ${ }^{\circledR}$ and Rheumax ${ }^{\circledR}$ commonly trade in the market to treat arthritis and related disorders, had been investigated regarding their quality control through selecting representative marker components from each drug. Different chromatographic procedures had been applied of which, a new validated HPLC method was developed for the simultaneous quantification of three active components (curcumin, demethoxycurcumin, bisdemethoxycurcumin, quercetin, and myristicin). Additionally, GC-FID was used for the relative quantification of fatty acids known for their anti-inflammatory activity in the hexane extract of the selected products. LC-MS-MS and GC-MS techniques were applied to tentatively identify some naturally occurring COX-2 inhibitors in methanol extract and fatty acid of the selected products, respectively. One of the products was adulterated by curcumin and surprisingly had no limonene or myristicin even it had celery seed as the pharmaceutical company said. The validation showed good linearity ( $\mathrm{R}$ is between 0.9990 and 0.9998 ), sensitivity (LODs $0.1-0.4 \mu \mathrm{g}$ ), precision (RSD < 2\%), and accuracy $(99.82-101.4 \%$ ) of the method. The developed HPLC method was proved to be a useful tool in the quality control of complex matrices of the selected polyherbal formulations. Many active components with anti-inflammatory effects were identified in the fixed oils, methanol, and hexane extracts of the HMs, so patients could take these herbal products with confidence about good quality and no chemical adulteration.
\end{abstract}

Keywords: herbal medicines, quality control, HPLC, LC-MS-MS, GC-MS, GC-FID

Herbal medicines (HMs) are getting more and more attention every day (1). They have been used for thousands of years all over the world. Many people feel more comfortable using herbal medicines than the synthesized ones because of their natural origin and generally claimed to be safer showing milder side effects. Extracts of herbal drugs represent a very complex matrix with a large number of low molecular weight secondary metabolites working together to provide healing properties to different ailments. However, the nature of these metabolites is subjected to variation both in a qualitative and quantitative manner due to different conditions including different harvest seasons, plant origins, processing, and other factors. Furthermore, these chemical constituents may be affected during pharmaceutical manufacturing and storage in pharmacies (2).

There is no authenticated technique powerful enough to identify and quantify all the ingredients in
HMs because of the uncertainty and the complexity of these ingredients (3). Hence, there is a great difficulty in developing the specific and objective method of quality control of HMs. Based on this point, adulterated or mediocre quality drugs appeared in markets $(4,5)$.

The chromatographic profile of an HM is a chromatographic pattern of the extract of some common chemical constituents of pharmacologically active or chemically characteristics (2). It refers to the profiles of the analyte obtained by certain analysis techniques such as high-performance liquid chromatography (HPLC), gas chromatography (GC), thin-layer chromatography (TLC), and spectral profile, for instance, UV, IR, MS, so on, and their hyphenated techniques. Chemical profiling is now internationally established as a quality evaluation model of herbal medicine.

\footnotetext{
* Corresponding author: e-mail: dr.nathalooo@hotmail.com
} 
Among the herbal-based pharmaceutical products, Voltarit ${ }^{\circledR}$ and Rheumax ${ }^{\circledR}$ are used in Syria to treat arthritis and related disorders. The first one contains five herbs including Apium graveolens (Celery), Crataegus laevigata (Hawthorn berries), Curcuma longa (Turmeric), Harpagophytum procumbens (Devil's claw, Pedaliaceae) and Vaccinium myrtillus (Bilbery) and the second contains four herbs including Curcuma longa (Turmeric), Boswellia serrata, Tinospora cordifolia and Vitex negunda. To date, many types of components have been reported in these herbs, including curcuminoids (i.e., curcumin), flavonoids (i.e., catechin, quercetin, rutin, kaempferol, apigenin, vitexin, and their glycosides), iridoids (i.e., harpagide and harpagoside), phenylpropanoids (chlorogenic acid), terpenoids and others. The extracts of each plant have been proven to have anti-inflammatory properties with cyclooxygenase enzyme inhibitors especially cyclooxygenase-2 (COX-2) being the most vulnerable target (6) Inhibitors of cyclooxygenases (COX) have emerged as important targets for treating rheumatoid arthritis, so COX inhibitors containing in the nine herbs might be responsible, at least in part, for the anti-inflammatory activity of the studied HMs (7).

Because of the complexity of herbal medicines, generally, only one, two, or three components are measured as an index of the quality of these medicines (8).

In this study, identification and quantification analysis of COX-2 inhibitors in two herbal medicines was performed. Several analytical methods have been used for the quality control of Voltarit ${ }^{\circledR}$ and Rheumax $^{\circledR}$, in order to answer the question: what do these herbal medicines contain after all the processes they came through?

\section{EXPERIMENTAL}

\section{HPLC analysis}

\section{Samples, materials, and reagents}

Standards of Curcumin (CUR), quercetin (QUER), and myristicin (MYR) were purchased from Sigma-Aldrich and used solvents were of HPLC grade (Merck).

Voltarit $^{\circledR}$ tablets and Rheumax ${ }^{\circledR}$ capsules (three different patches for both) were purchased from a local pharmacy.

\section{Chromatographic conditions}

HPLC analysis was carried out on an Agilent 1100 liquid chromatography system. Column: Eclipse plus C18 column ( $5 \mu \mathrm{m}, 4.6 \mathrm{~mm} \times 150 \mathrm{~mm})$. Mobile phase: acetonitrile : $2 \%$ acetic acid (40:60).
Detection wavelength: using photodiode array detector set at $282 \mathrm{~nm}$ (for MYR) - $370 \mathrm{~nm}$ (for CUR and QUER). Injection volume: $20 \mu \mathrm{L}$. Flow rate: $1 \mathrm{~mL} /$ min. PH: 2.6. Temperature: $35^{\circ} \mathrm{C}$.

\section{Standard solutions preparation}

Stock standard solutions were prepared by dissolving CUR, QUER, and MYR in methanol to obtain solutions having concentrations of $1 \mathrm{mg} / \mathrm{mL}$ for each. The mixture of working standard solutions of CUR, QUER, and MYR were prepared in the range $(1-10 \mu \mathrm{g} / \mathrm{mL})$. This mixture was injected into the HPLC system in different concentrations. Then the calibration curve was prepared by plotting these concentrations vs their peak areas.

\section{Sample solutions preparation}

The average weight of one tablet of Voltarit ${ }^{\circledR}$ was determined after weighing 20 tablets. An amount of powdered tablets equivalent to $1 \mathrm{gr}$ was transferred into a $10 \mathrm{~mL}$ volumetric flask of methanol. The solution was sonicated for $1 \mathrm{~h}$ at $60^{\circ} \mathrm{C}$. This test solution was filtered and injected directly into the HPLC system. The average weight of one capsule of Rheumax ${ }^{\circledR}$ was determined after emptying the content of 20 capsules. Then the test solution of Rheumax ${ }^{\circledR}$ was prepared exactly the same as the Voltarit ${ }^{\circledR}$ test solution.

\section{HPLC method validation}

The proposed HPLC method for simultaneous determination of curcumin, quercetin, and myristicin was validated according to ICH guidelines. So linearity and range, limits of detection (LODs), limits of quantitation (LOQs), Accuracy (\%RSD), Trueness (the difference between the mean $\mathrm{x}$ and the reference value or the recovery rate (\%error), precision (\%Recovery) and robustness were evaluated.

\section{GC-MS analysis}

Method: Agilent 7890A (column DB 5-MS). Carrier gas helium $(1.7 \mathrm{~mL} / \mathrm{min})$; injection volume $1 \mu \mathrm{L}$; temperature program: $60^{\circ} \mathrm{C}(1 \mathrm{~min}), 60-140^{\circ} \mathrm{C}$ at $3^{\circ} \mathrm{C} / \mathrm{min}, 50-250^{\circ} \mathrm{C}(3 \mathrm{~min})$. Detector temperature: $150^{\circ} \mathrm{C}$ injector temperature: $250^{\circ} \mathrm{C}$.

\section{Sample preparation}

Soxhlet extraction was done using an SER 148 (Velp Scientifica) solvent extractor. For each sample, $10 \mathrm{~g}$ of powder were packed in a thimble and extracted with hexane : acetone $(1: 1)(150 \mathrm{~mL})$. The extraction steps were performed at $60^{\circ} \mathrm{C}$ and lasted for $5 \mathrm{~h}$. The extracts were evaporated by nitrogen evaporation. Then $2 \mathrm{~mL}$ hexane was added and the hexane extracts filtered and injected into GC-MS. 


\section{LC-ESI-MS analysis}

Identification of some active components in the methanolic extracts of HMs was also confirmed by LC-MS-MS. The LC-MS was performed by using Agilent LC/MS/MS system (USA) with electrospray ionization (ESI). Column: Eclipse XDB C18, 4.6 $* 150 \mathrm{~mm}, 3.5 \mu \mathrm{m}$. Mobile phase: The mobile phase consisted of (A) aqueous formic acid $(0.1 \%$, $\mathrm{v} / \mathrm{v}$ ) and (B) acetonitrile, and the gradient elution scheme involved the use of $15-20 \% \mathrm{~B}$ at $0-5 \mathrm{~min}$, $20-28 \% \mathrm{~B}$ at $5-6 \mathrm{~min}, 28 \% \mathrm{~B}$ at $6-10 \mathrm{~min}, 28-35 \%$ $\mathrm{B}$ at $10-12 \mathrm{~min}, 35 \% \mathrm{~B}$ at $12-15 \mathrm{~min}$. Flow rate: $0.6 \mathrm{~mL} / \mathrm{min}$. Temperature: $35^{\circ} \mathrm{C}$. Mass spectrometry conditions: Detection was performed in the negative ion mode and full scan range from 100 to 2000 m/z. ESI: negative. Nebulizer gas: 40 psi. Drying gas flow: $11 \mathrm{~L} / \mathrm{min}$. Drying gas temp: 350 . Capillary 4500V.

\section{Sample preparation}

Twenty tablets of Voltarit ${ }^{\circledR}$ were crushed and twenty capsules of Rheumax ${ }^{\circledR}$ were opened. One gram of the powder of each was dissolved in $10 \mathrm{~mL}$ methanol and sonicated for $2 \mathrm{~h}$. The resulted extracts were filtered using $0.22 \mu \mathrm{m}$ syringe filters then injected directly to LC-MS-MS.

\section{GC-FID}

\section{Sample preparation \\ (Fischer-Speier esterification)}

Toluene $(0.3 \mathrm{~mL})$, methanol $(1.5 \mathrm{~mL})$, and the $8 \% \mathrm{HCl}$ solution $(3 \mathrm{~mL})$ were added sequentially to the sample of Voltarit ${ }^{\circledR}$ that was prepared in 2.2.1. Then the solution was heated at $100^{\circ} \mathrm{C}$ for an hour. After cooling, $1 \mathrm{~mL}$ hexane and $1 \mathrm{~mL}$ distilled water were added. After the vortex, the hexane layer was taken and injected into GC-FID.

\section{GC-FID conditions}

The carrier gas: Nitrogen $(30 \mathrm{~mL} / \mathrm{min})$. Injector temperature: $250^{\circ} \mathrm{C}$. Temperature program: $50^{\circ} \mathrm{C}$ for a minute, $25^{\circ} \mathrm{C} / \mathrm{min}$ to $200^{\circ} \mathrm{C}, 3^{\circ} \mathrm{C} / \mathrm{min}$ to $230^{\circ} \mathrm{C}$ (18 min). Injection volume: $1 \mu \mathrm{L}$, detector temperature: $280^{\circ} \mathrm{C}$.

\section{RESULTS AND DISCUSSION}

\section{HPLC analysis \\ Identification and quantification of curcumin, quercetin and myristicin}

Curcuminoids (a mixture of curcumin, demethoxycurcumin (DMC), and bisdemethoxycurcumin (BDMC)), quercetin, and myristicin were quantified in two commercial samples using the method developed and validated in the present work. Mixtures of standard solutions of CUR, QUER, and MYR were prepared and injected into HPLC. The HPLC chromatogram of the standard solutions is shown in Figure 1. The concentrations of analyzed compounds found in the two samples are listed in Table 1. MYR was not detected in Voltarit ${ }^{\circledR}$ or was below the limit of detection (LOD).

Table 1 . The quantity of components in the HMs by the proposed HPLC method.

\begin{tabular}{|c|c|c|}
\hline Component & $\begin{array}{c}\text { Voltarit }^{\circledR} \\
\mathrm{mg} / \text { tablet }\end{array}$ & $\begin{array}{c}\text { Rheumax } \\
\text { mg/capsule }\end{array}$ \\
\hline Quercetin & 0.014 & 0.005 \\
\hline Curcumin & 64.765 & 0.003 \\
\hline BDMC & 30.445 & 0.059 \\
\hline DMC & 70.84 & 0.008 \\
\hline Myristicin & 0 & 0.0025 \\
\hline
\end{tabular}

Figures 2 and 3 show the HPLC chromatogram of the methanolic extracts of Voltarit ${ }^{\circledR}$ and Rheumax $^{\circledR}$, respectively.

The main bioactive compounds isolated from rhizomes of Curcuma longa are Curcuminoids 


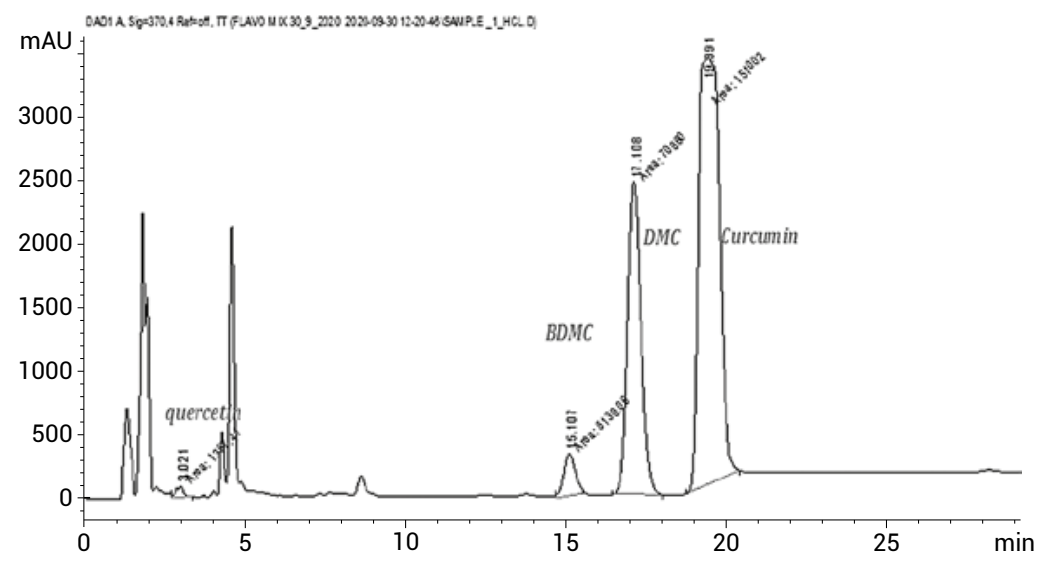

Figure 2. HPLC chromatogram of methanolic extract of Voltarit ${ }^{\circledR}$.

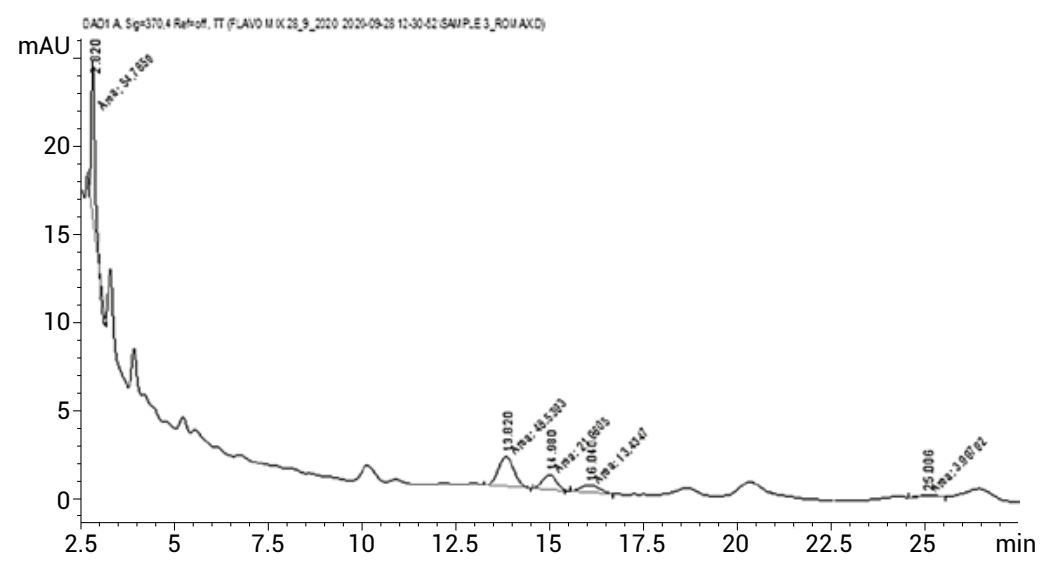

Figure 3. HPLC chromatogram of methanolic extract of Rheumax ${ }^{\mathbb{R}}$.

and sesquiterpenoids (germacrone, turmerone, $\beta$-turmerones, $\beta$-bisabolene, $\alpha$-curcumene, Turmerone 8.0-28.4\%, ar-Curcumene 2.8-3\%, etc). Curuminoid is a potent anti-inflammatory agent. It causes a reduction in cytokines, LTs, and PGs levels by inhibition of COX-2, 5-LOX, and other mediators $(9,10)$.

Therefore, analysis of main compounds existing in Curcuma longa is of importance for the authentication of plant material, checking quality, and for research purposes.

The curcuminoid contains only $2.5-6 \%$ curcumin which compromises approximately $77 \%$ of the curcuminoid content. One tablet of Voltarit ${ }^{\circledR}$ contains $75 \mathrm{mg}$ turmeric rhizomes, so we can expect not more than $4.5 \mathrm{mg}$ of curcumin in one tablet. Actually, more than $60 \mathrm{mg}$ was quantified in Voltarit ${ }^{\circledR}$ tablet and it suggests that the curcumin was adulterated.

According to studies, Celery seed extract has anti-inflammatory activity and the oil of seeds contain $(0.18 \%)$ myristicin which could be categorized as a non-selective inhibitor of COX-2 $(11,12)$. Myristicin was not detected in the methanol extract of Voltarit ${ }^{\circledR}$ and that was surprising because celery seed is considered from the top plants containing myristicin however, the methanol is the most commonly used extraction solvent for myristicin isolation $(13,14)$.

Quercetin, one of the most well-known flavonoids, has been reported to have potent anti-inflammatory effects (15). It significantly suppressed COX-2 mRNA and protein expression and prostaglandin (PG) E (2) production (16). It is found in Curcuma longa (17), Apium graveoleus (in the methanolic extract $56.95 \pm 7.14 \mathrm{mg} / \mathrm{g}$ ) (18), Hawthorn berries (19), Vaccinium myrtillus (20), Tinospora cardifolia (21), Boswellia serrata (22) and Vitex negundo (13.45 mg/g) (23). Quercetin was quantified in both products $0.014 \mathrm{mg} /$ tablet in Voltarit ${ }^{\circledR}$ and $0.005 \mathrm{mg}$ / capsule in Rheumax ${ }^{\circledR}$. It was noted that the content of quercetin was too small compared to the literature.

\section{Method validation}

In this study, three bioactive compounds, belonging to three families of compounds, were 
determined simultaneously in order to evaluate the quality of the commercial products. The calibration plots for curcumin, DMC, BDMC, quercetin and myristicin showed excellent linearity R2 $=0.9992$, $\mathrm{R} 2=0.9990, \mathrm{R} 2=0.9998, \mathrm{R} 2=0.9992$ and $\mathrm{R} 2=0.9995$, respectively. The concentration ranges of standards were from $1 \mu \mathrm{g} / \mathrm{mL}$ to $10 \mu \mathrm{g} / \mathrm{mL}$. The LODs and LOQs of standards are listed in Table 2. To estimate repeatability (precision), Rheumax ${ }^{\circledR}$ was spiked with curcumin, quercetin, and myristicin solutions $(5 \mathrm{~mL}, 5 \mu \mathrm{g} / \mathrm{mL})$, and the concentrations were calculated six times in a day and on three different days. To estimate the accuracy (recovery) and trueness, standard solutions of curcumin, quercetin, and myristicin were prepared (three different concentrations $5,10,15 \mu \mathrm{g} / \mathrm{mL}$ for each one). The examined method showed high accuracy (high\%recovery) and trueness (\%error) (Table 3) and excellent precision $(\%$ RSD < 2) $($ Table 4). Method validation revealed that the developed HPLC method is suitable for simultaneous qualitative and quantitative analysis of CUR, QUER, and MYR in HMs.

Table 2. Limits of detection (LODs) \& limits of quantitation (LOQs) of standards.

\begin{tabular}{|c|c|c|}
\hline Compound & $\begin{array}{c}\text { LOD } \\
(\mu \mathrm{g} / \mathrm{mL})\end{array}$ & $\begin{array}{c}\text { LOQ } \\
(\mu \mathrm{g} / \mathrm{mL})\end{array}$ \\
\hline QUER & 0.2 & 0.5 \\
\hline CUR & 0.1 & 0.3 \\
\hline BDMC & 0.4 & 0.7 \\
\hline DMC & 0.3 & 0.5 \\
\hline MYR & 0.3 & 0.6 \\
\hline
\end{tabular}

Signal to noise (LOD): 3 ; signal to noise (LOQ): 10

Table 3. Evaluation of accuracy and trueness of the proposed HPLC method.

\begin{tabular}{|c|c|c|c|}
\hline & \multicolumn{3}{|c|}{ Recovery\% $(1)$} \\
\hline Amount added $(\mu \mathrm{g} / \mathrm{mL})$ & CUR & 100.1 & QUER \\
\hline 5 & 99.98 & 100.4 & 99.82 \\
\hline 10 & 100.8 & 101.2 & 100.9 \\
\hline 15 & 101.4 & 100.566 & 100.236 \\
\hline Mean\%(2) & 100.726 & 0.566 & 0.236 \\
\hline Trueness: Error\% or $\mid$ Mean-x| (3) & 0.726 & 0.4642 & 0.474 \\
\hline SD (4) & 0.581 & 0.461 & 0.473 \\
\hline
\end{tabular}

(1) Recovery of each individual assay (the concentrations are $5,10,15 \mu \mathrm{g} / \mathrm{mL}$ for each of CUR, QUER, and MYR).

(2) The mean of all recoveries $(\mathrm{n}=3)$.

(3) |Mean-x|: The mean - reference value.

(4) Standard deviation of the recoveries.

(5) Percentage relative standard deviation of all determinations.

Table 4. Evaluation of precision of the proposed HPLC method.

\begin{tabular}{|c|c|c|c|c|c|c|c|}
\hline \multicolumn{3}{|c|}{ Intra-day repeatability } & \multicolumn{4}{c|}{ Inter-day repeatability } \\
\hline \multicolumn{3}{|c|}{ Recovery\% (1) } & \multicolumn{3}{c|}{ Recovery\% } \\
\hline NO. & CUR & QUER & MYR & Day & CUR & QUER & MYR \\
\hline 1 & 100.2 & 100.1 & 99.99 & 1 & 100.1 & 100.1 & 99.99 \\
\hline 2 & 100 & 100.3 & 100.1 & 2 & 100.7 & 100.4 & 100.9 \\
\hline 3 & 100.5 & 101.4 & 99.98 & 3 & 100.9 & 101.2 & 99.82 \\
\hline 4 & 100.5 & 100.5 & 100 & Mean\% & 100.566 & 100.566 & 100.236 \\
\hline 5 & 100.8 & 100.8 & 100.5 & SD & 0.3399 & 0.4642 & 0.474 \\
\hline 6 & 100.1 & 100.3 & 99.5 & RSD\% & 0.338 & 0.461 & 0.473 \\
\hline Mean\% (2) & 100.35 & 100.56 & 100.01 & & & & \\
\hline SD (3) & 0.2753 & 0.43 & 0.2914 & & & & \\
\hline RSD $\%(4)$ & 0.274 & 0.427 & 0.291 & & & & \\
\hline
\end{tabular}

(1) Recovery of each individual assay (the concentration is $5 \mu \mathrm{g} / \mathrm{mL}$ for each of CUR, QUER, and MYR).

(2) The mean of all recoveries $(n=6)$. The mean of all recoveries $(n=3)$.

(3) Standard deviation of the recoveries.

(4)Percentage relative standard deviation of all determinations. 


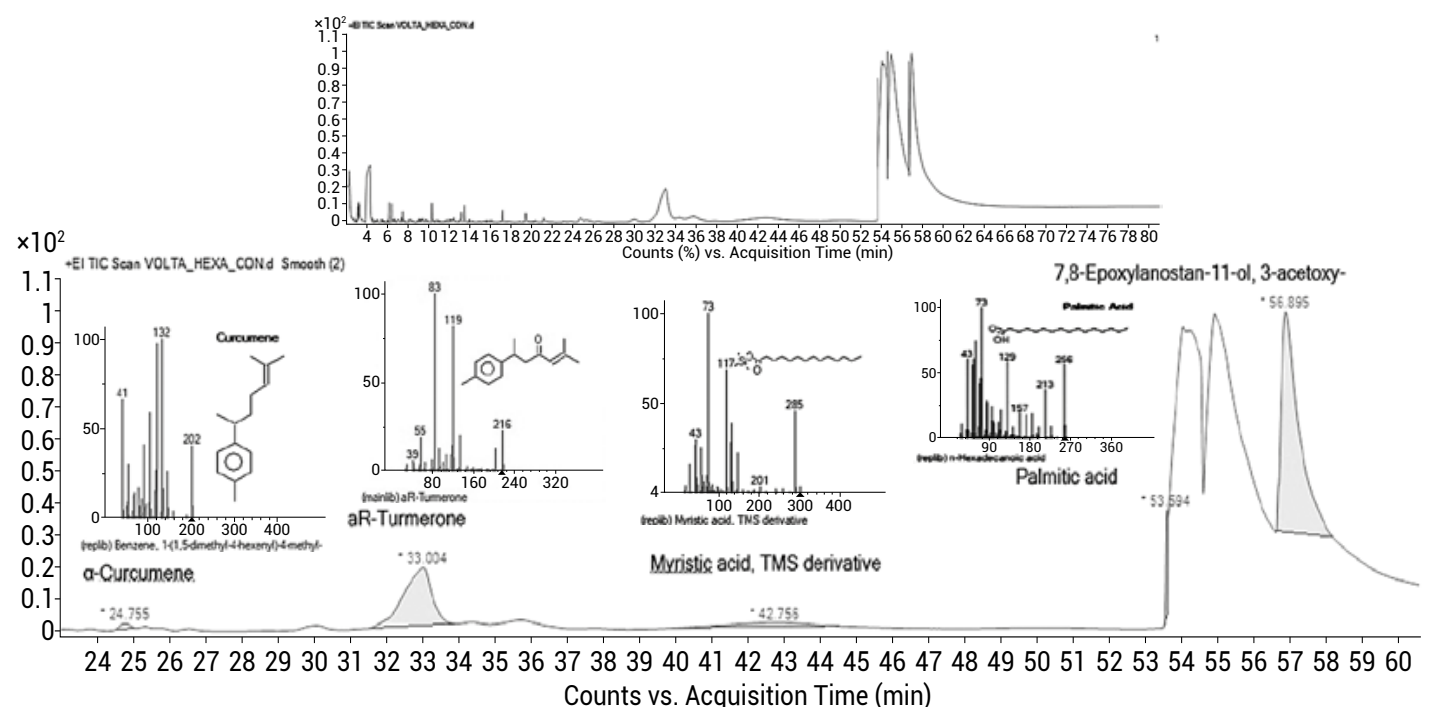

Figure 4. Total ionic chromatogram (GC-MS) of hexane extract of Voltarit ${ }^{\circledR}$.

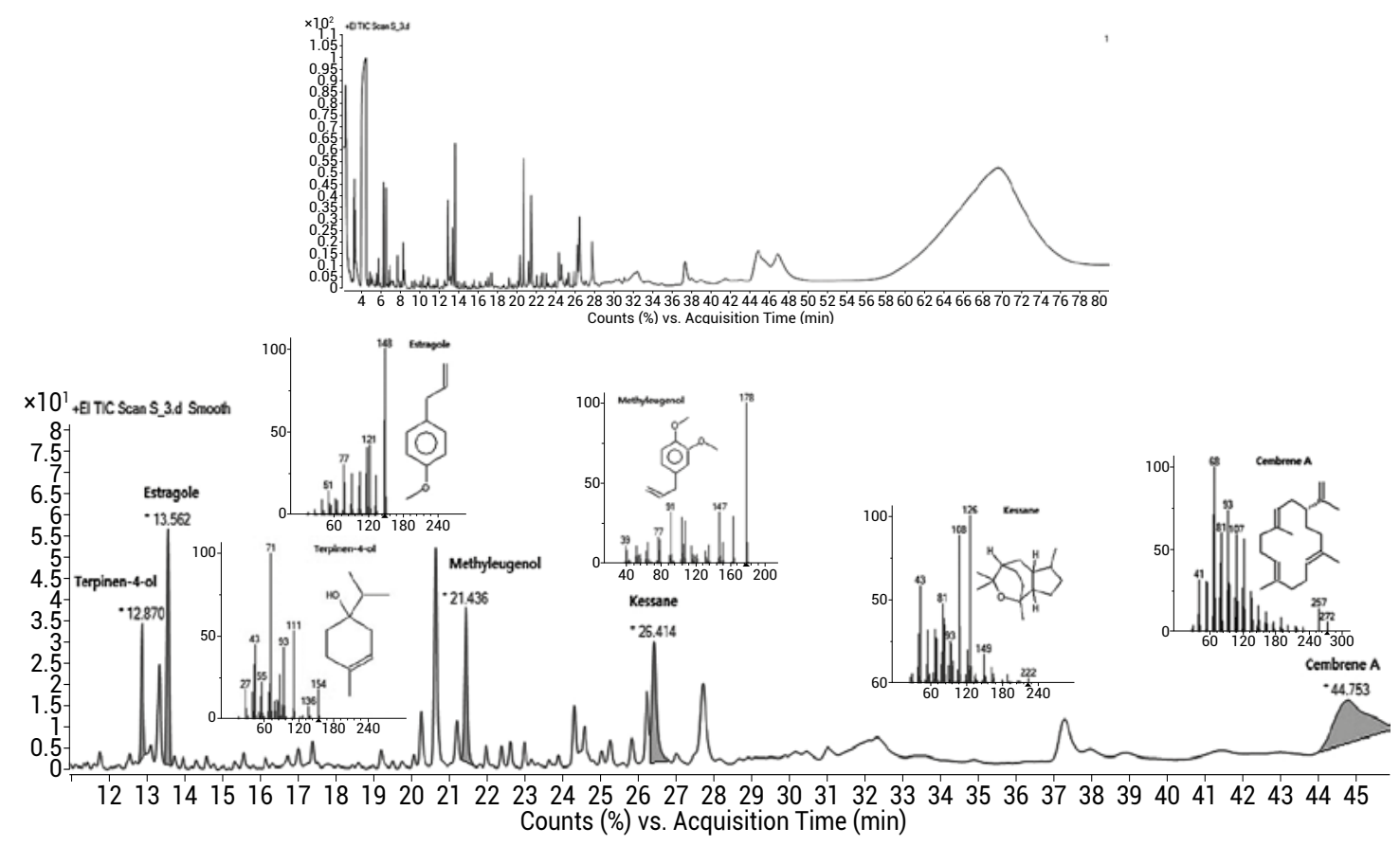

Figure 5. Total ionic chromatogram (GC-MS) of hexane extract of Rheumax ${ }^{\circledR}$..

\section{GC-MS analysis}

GC-MS chromatograms of Voltarit ${ }^{\circledR}$ and Rheumax $^{\circledR}$ are shown in Figures 4 and 5, respectively. The compounds detected in the fixed oil of the two samples are summarized in Table 5. The determination of the compounds was based on the match with the ion fragmentation patterns of the reference peaks in the NIST MS library.

Among all the compounds detected in the nhexane extracts by GC-MS, some compounds have an anti-inflammatory effect and inhibitory activity of COX-2, such as $\alpha$-curcumene, $\alpha$-turmerone, palmitic acid, and myristic acid in Voltarit ${ }^{\circledR}$ and terpinen-4-ol, estragole, methyleugenol, kessane, epiglobulol and cembrene A in Rheumax ${ }^{\circledR}$. The existence of fatty acids in Voltarit ${ }^{\circledR}$ leads us to detect more by GC-FID which is discussed in 3.4.

The essential oil of turmeric rhizomes was found to contain many sesquiterpenes, including, turmerone $8.0-28.4 \%$, $\alpha r$-turmerone $15.5-27.5 \%$, $\alpha$-curcumene $2.8-3 \%$. So we can consider $\alpha r$ turmerone and $\alpha$-curcumene, which are detected in the oil of Voltarit ${ }^{\circledR}$, as the marker compounds for the presence of turmeric in our herbal medicine (24). 
Table 5. the compounds which were detected in the fixed oil of the two samples by GC-MS.

\begin{tabular}{|c|c|c|c|c|c|}
\hline $\begin{array}{c}\text { Compounds in oil of } \\
\text { Voltarit } \AA\end{array}$ & $\begin{array}{l}\text { Retention } \\
\text { time (min) }\end{array}$ & $\begin{array}{c}\text { GC-MS Peak } \\
\text { area [\%] }\end{array}$ & $\begin{array}{c}\text { Compounds in oil of } \\
\text { Rheumax }{ }^{\circledR}\end{array}$ & $\begin{array}{l}\text { Retention time } \\
\text { (min) }\end{array}$ & $\begin{array}{c}\text { GC-MS Peak area } \\
{[\%]}\end{array}$ \\
\hline 2-methyl-5-nonanol & 3.343 & 0.51 & n-Hexane e & 2.347 & 3.44 \\
\hline Diacetone alcohol & 4.356 & 8.47 & 2-Hexane one & 3.206 & 1.19 \\
\hline $\begin{array}{c}\text { Ethanone, } \\
\text { 1-(3-ethyloxiranyl)- }\end{array}$ & 6.215 & 0.39 & $\begin{array}{c}\text { 2-Pentanone, } \\
\text { 4-hydroxy-4-methyl- }\end{array}$ & 4.407 & 8.55 \\
\hline Valeric anhydride & 6.456 & 0.41 & Valeric anhydride & 6.46 & 0.82 \\
\hline undecane & 10.324 & 0.38 & Terpinen-4-ol & 12.87 & 0.77 \\
\hline Ethyl amyl carbinol & 13.253 & 0.35 & Estragole & 13.562 & 0.78 \\
\hline Dodecane & 13.545 & 0.43 & (-)- $\beta$-Bourbonene & 20.635 & 0.91 \\
\hline Tridecane & 17.219 & 0.33 & Methyleugenol & 21.436 & 0.92 \\
\hline Valerophenone & 19.45 & 0.36 & Kessane & 26.414 & 0.77 \\
\hline$\alpha$-curcumene & 24.755 & 0.45 & $\begin{array}{c}\text { Benzene, 1,2,3-trimethoxy- } \\
\text { 5-(2-propenyl)- }\end{array}$ & 27.702 & 0.89 \\
\hline$( \pm)$-trans-nuciferol & 30.048 & 0.56 & Epiglobulol & 32.311 & 1.21 \\
\hline$\alpha \mathrm{R}$-Turmerone & 32.995 & 10.84 & $\alpha$-Phellandrene, dimer & 37.263 & 0.99 \\
\hline Isosericenin & 35.69 & 1.13 & Cembrene A & 44.753 & 3.06 \\
\hline $\begin{array}{c}\text { Myristic acid, TMS } \\
\text { derivative }\end{array}$ & 42.722 & 2.91 & Verticiol & 46.819 & 2.93 \\
\hline Palmitic acid & 53.577 & 0.33 & Thunbergol & 69.547 & 72.77 \\
\hline $\begin{array}{c}\text { Docosanoic acid, } 1,2,3- \\
\text { propanetriyl ester }\end{array}$ & 54.046 & 17 & & & \\
\hline Dipalmitin & 54.578 & 0.28 & & & \\
\hline $\begin{array}{c}\text { 7,8- Epoxylanostan-11- } \\
\text { ol, 3-acetoxy- }\end{array}$ & 54.916 & 50 & & & \\
\hline
\end{tabular}

Many studies have been demonstrated the antiinflammatory and anti-arthritis effects of Boswellia serrata (25) and more than 340 volatiles in Boswellia have been reported in the literature, including cembrene, Methyleugenol, Estragole, terpinen-4-ol, and kessane which were detected by GC-MS in our study. The transcriptional inhibition of cembranoid diterpenes was confirmed by a decrease in COX-2 and inducible nitric oxide synthase (iNOS) gene expression levels (26).

Eugenol interacts with COX-2 and is used as an analgesic in dentistry. Its derivative methyleugenol has an anesthetic action in rodents. Estragole inhibits the lipopolysaccharide LPS-induced expression of inflammatory mediators via the downregulation of COX-2 and other pathways, indicating that this phenylpropanoid has potential therapeutic and preventive applications in various inflammatory diseases (27).

Terpinen-4-ol can suppress the production of inflammatory mediators in LPS stimulated human macrophages and interfering with many inflammatory pathways (28).
There was no limonene in the hexane extract of Voltarit ${ }^{\circledR}$, although it is the chief component of the celery seed oil (about $70 \%$ to $80 \%$ ).

\section{LC-MS-MS analysis}

The full scan in a negative ion mode (scan range $\mathrm{m} / \mathrm{z} 100 \rightarrow 2000$ ) was used to identify COX-2 inhibitors in the methanolic extracts of both Voltarit ${ }^{\mathbb{B}}$ and Rheumax ${ }^{\circledR}$ focusing on the components we knew it could be in the herbs, especially flavonoids. The peaks of these components were characterized by comparing the retention time and fragmentation information with the reference (8) (mass bank). Flavonoids like Catechin, Quercetin-3-O-neohesperidoside, Rutin, Kaempferol-3-O-(2G- $\alpha$-L-rhamnosyl)- rutinoside, Kaempferol-3-O-neohesperidoside, and Apigenin, besides other compounds like harpagoside, verbascoside, Coumaroylquinic acid, Curcumin, and his metabolite DMC were identified in Voltarit ${ }^{\circledR}$ (Table 6). Anti-inflammatory effect and inhibitory one on cyclooxygenase- 2 were proved to many flavonoids (29, 30, 31). Harpagoside (iridoid glycoside) and Verbascoside (phenylenthanoid glycoside), which 
Table 6. The compounds identified in the methanolic extracts of Voltarit and Rheumax ${ }^{\circledR}$ and their mass spectrometry data.

\begin{tabular}{|c|c|c|c|}
\hline & Compound & $\begin{array}{c}\text { Retention times(Rt) } \\
(\mathrm{min})\end{array}$ & $\begin{array}{c}\text { Negative ion mode } \\
(\mathrm{m} / \mathrm{z})\end{array}$ \\
\hline Voltarit $^{\circledR}$ & Verbascoside & 1.872 & $665.0-623.1-503.2$ \\
\hline & Catechin & 5.066 & $289.1-245$ \\
\hline & Quercetin-3-O-neohesperidoside & 8.102 & $609.1-301$ \\
\hline & Rutin & 9.837 & $609.2-301$ \\
\hline & Kaempferol-3-O-(2G- $\alpha$-L-rhamnosyl)- rutinoside & 11.339 & $740-227$ \\
\hline & Kaempferol-3-O-neohesperidoside & 14.068 & $593.2-285.1$ \\
\hline & Harpagoside & 14.480 & $493.2-146.9$ \\
\hline & Apigenin & 16.405 & $269.2-118$ \\
\hline & DMC & 17.822 & $337.2-163$ \\
\hline & Curcumin & 18.637 & $367.2-337.1-217$ \\
\hline & Isovitexin -7 -O glycoside & 1.703 & $593.2-379.1-367.2$ \\
\hline & Chlorogenic acid & 2.052 & $353.1-190.9-179.1-135.1$ \\
\hline & Apigenine 6-C-glocoside 8-C-arabinoside & 7.859 & $565-415-295$ \\
\hline & P-Coumaric acid & 10.376 & $162.9-118.8$ \\
\hline & Vitexin(Apigenin-8-C-glucoside) & 10.852 & $415.3-367.1-312.2$ \\
\hline
\end{tabular}

$\times 10^{6} \quad$ ESI TIC Scan Frag-120.0V 378 S1 Volt.d

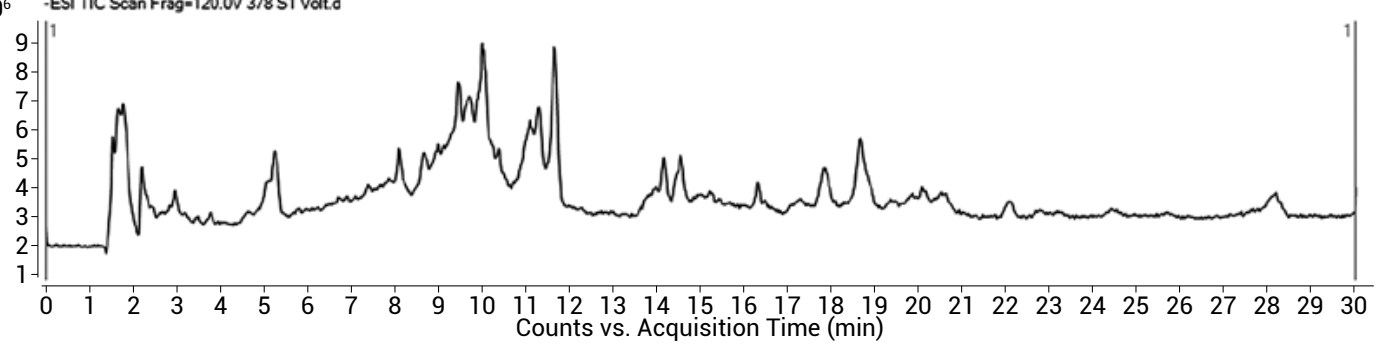

Figure 6. LC-negative ion ESI-MS TIC profile of the extract of Voltarit ${ }^{\circledR}$.

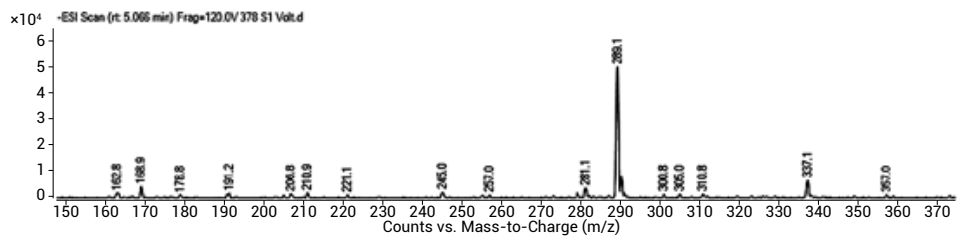

were isolated from devil's claw, inhibit COX-1/2 activity in whole human blood $(7,32)$.

The anti-inflammation effect of coumaroylquinic acid, a chlorogenic acid, was demonstrated by
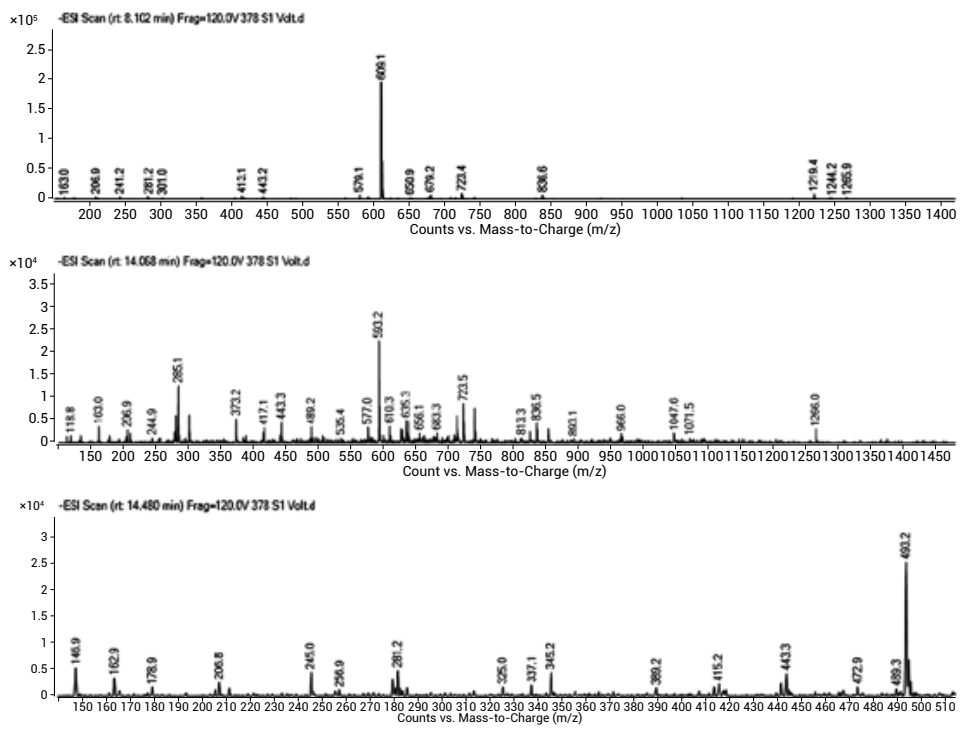
the reduced expression of cyclooxygenase-2 (COX-2) and tumor necrosis factor- $\alpha$ (TNF- $\alpha)$ (33).

Figures 6 and 7 show the LC-ESI-MS chromatogram of the

Figure 7. ESI-MS scan spectra of compounds: (A) catechin, (B) Quercetin3-O-neohesperidoside, (C) Kaempferol-3O-neohesperidoside, (D) harpagoside.

(A) Catechin (precursor ion $289.1 \mathrm{~m} / \mathrm{z}$ product ion $245 \mathrm{~m} / \mathrm{z}$ ).

(B) Quercetin-3-O-neohesperidoside (precursor ion $609.1 \mathrm{~m} / \mathrm{z}$ product ion $301 \mathrm{~m} / \mathrm{z}$ ).

(C) Kaempferol-3-O-neohesperidoside (precursor ion $593.2 \mathrm{~m} / \mathrm{z}$ product ion $285.1 \mathrm{~m} / \mathrm{z}$ ).

(D) Harpagoside (precursor ion $493.2 \mathrm{~m} / \mathrm{z}$ product ion $146.9 \mathrm{~m} / \mathrm{z}$ ) 


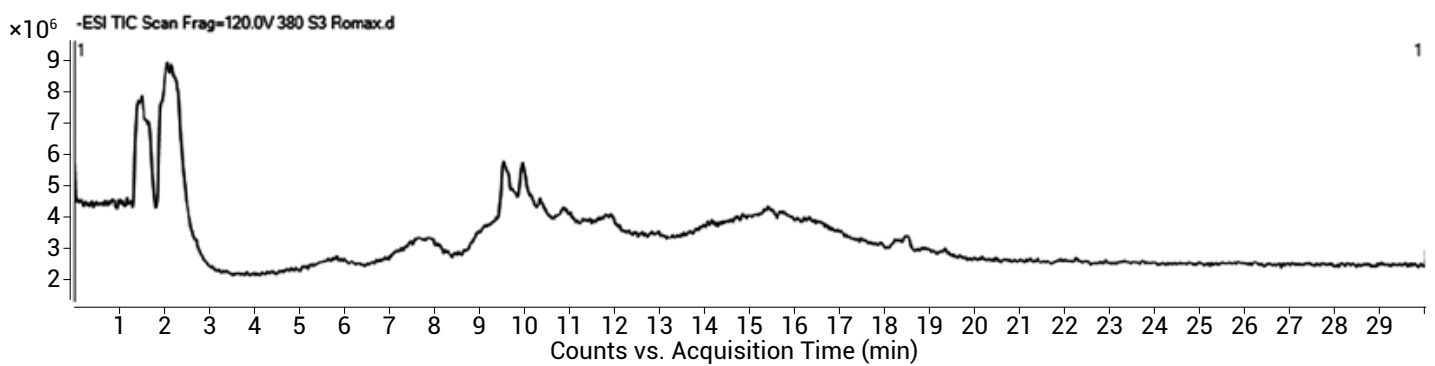

Figure 8. LC-negative ion ESI-MS TIC profile of the extract of Rheumax ${ }^{\circledR}$.

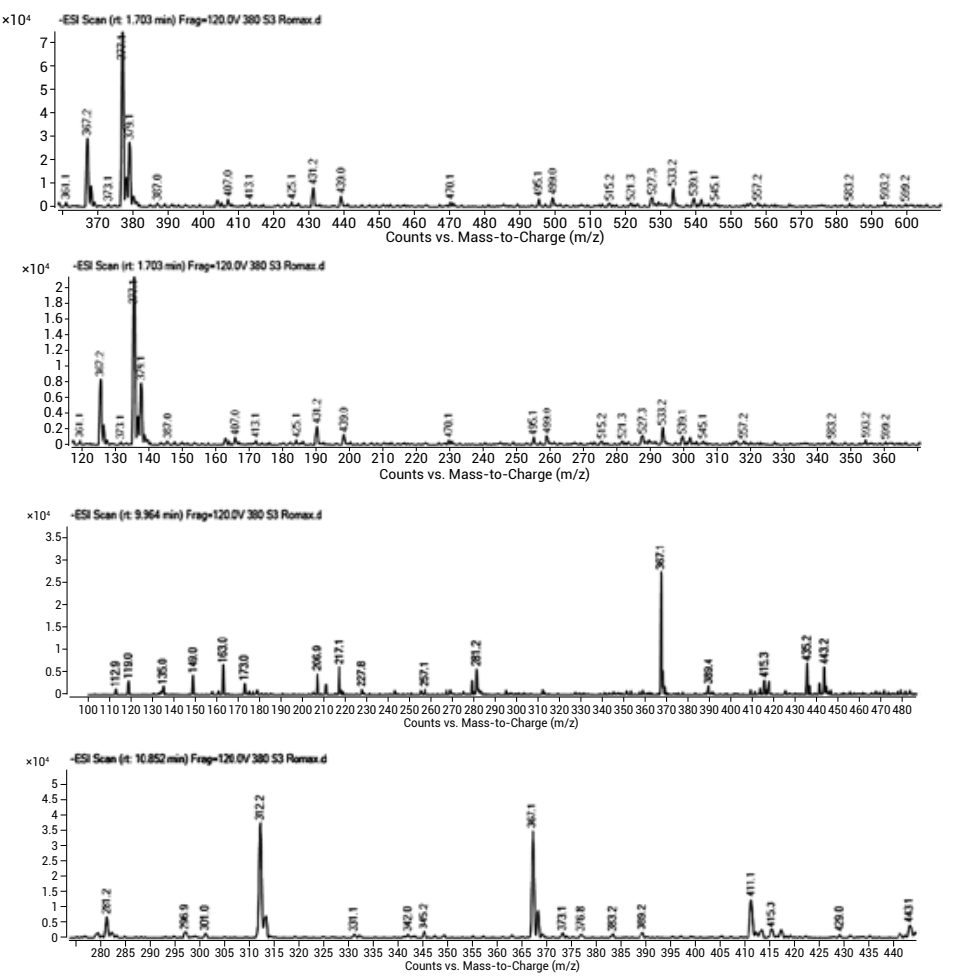

Figure 9. ESI-MS scan spectra of compounds: (F) Iso vitexin -7 $-\mathrm{O}$ glycoside, $(\mathrm{G})$ chlorogenic acid $(\mathrm{H})$ curcumin (I) Vitexin (Apigenin-8-Cglucoside).

(F) Iso vitexin -7 -O glycoside (precursor ion $593.2 \mathrm{~m} / \mathrm{z}$ product ion 379.1 $367.2 \mathrm{~m} / \mathrm{z}$ ).

(G) Chlorogenic acid (precursor ion $353.1 \mathrm{~m} / \mathrm{z}$ product ions $190.9-179.1$ $135.1 \mathrm{~m} / \mathrm{z})$.

(H) Curcumin (precursor ion $367.1 \mathrm{~m} / \mathrm{z}$ product ion 217.1 ).

(I) Vitexin (Apigenin-8-C-glucoside) (precursor ion 415.3 product ion 367.1-312.2 m/z.)

Figures 8 and 9 show the LCESI-MS chromatogram of the extract of Rheumax ${ }^{\circledR}$ and the MS-MS spectra of some compounds identified in this extract, respectively. The precursor ion, product ions, and retention time of each compound that identified in the methanolic extracts of both Voltarit ${ }^{\circledR}$ and Rheumax $^{\circledR}$ are shown in Table 6 .

extract of Voltarit ${ }^{\circledR}$ and the MS-MS spectra of some compounds identified in this extract, respectively.

Curcumin, flavonoids (isovitexin -7 -O glycoside, apigenine 6-C-glocoside 8-C-arabinoside, vitexin (apigenin-8-C-glucoside), chlorogenic acid, and P-coumaric acid were identified in Rheumax $^{\circledR}$ (Table 6).

Boswellia serrata (Salai Guggul), Curcuma longa (Haldi), and Vitex negundo (Nirgundi) have properties that can significantly reduce joint pain or swelling and have no side effects (34). Vitexin and isovitexin, flavonoids (apigenin isomers) isolated from these herbs and Tinospora cordifolia, were found to possess anti-inflammatory properties. They inhibit many inflammation mediators including COX-2. $(35,36)$. Coumaric acid CA, which was found in Curcuma longa and Tinospora cordifolia, demonstrated promising anti-arthritic effects and reduced the inflammatory enzymes (iNOS and COX-2) (37).

\section{GC-FID}

Some natural fatty acids were detected in the hexane extract of Voltarit ${ }^{\circledR}$ and summarized in Table 7 with their retention time and percentage. These fatty acids inhibit COX-2-catalyzed prostaglandin biosynthesis, so they have anti-inflammatory effects (38). Figure 10 shows the GC-FID chromatogram of the esterified hexane extract of Voltarit ${ }^{\circledR}$.

Table 7. The fatty acids quantified in Voltarit ${ }^{\circledR}$ by GC-FID.

\begin{tabular}{|c|c|c|}
\hline Component & $\begin{array}{c}\text { Ret. time } \\
(\mathrm{min})\end{array}$ & $\begin{array}{c}\text { Area unit } \\
(\%)\end{array}$ \\
\hline Palmitic acid & 14.337 & 10.951 \\
\hline Palmitoleic acid & 14.782 & 0.500 \\
\hline Stearic acid & 17.449 & 4.575 \\
\hline Oleic acid & 17.911 & 75.236 \\
\hline Linoleic acid & 18.884 & 8.738 \\
\hline
\end{tabular}




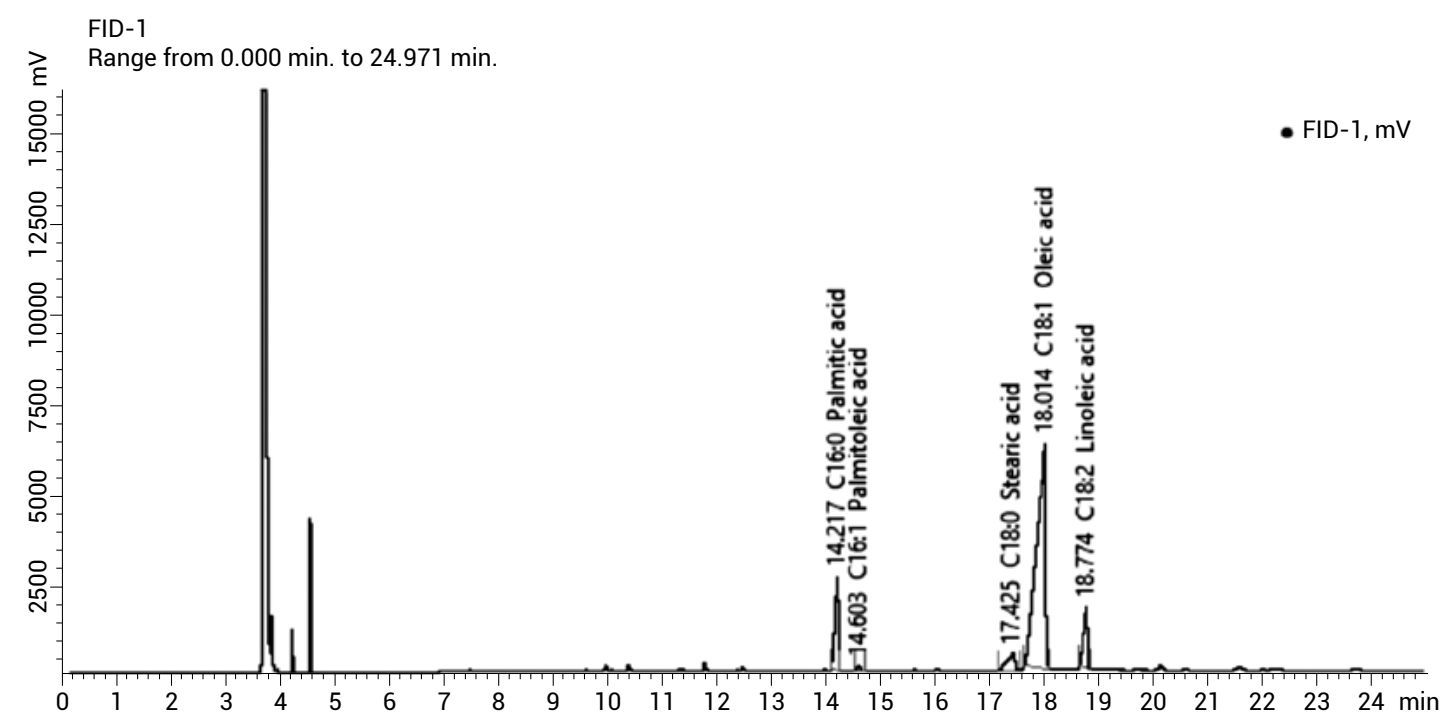

Figure 10. The GC-FID chromatogram of the esterified hexane extract of Voltarit ${ }^{\circledR}$.

\section{CONCLUSION}

A newly developed HPLC has been established for the first time in order to quantitatively determine three bioactive components of two herbal products simultaneously. Analytical techniques involving GC-FID, GC-MS, and LC-MSMS were successfully employed as quality control methods for herbal medicines. One of the products was adulterated by curcumin as it has antiinflammatory properties and not expensive material. Many natural COX-2 inhibitors were detected in the fixed oils, methanolic and hexane extracts of the HMs. These COX-2 inhibitors and other detected bioactive constituents may be responsible, at least in part, for the anti-inflammatory activity of the HMs.

This is the first report where different chromatographic techniques, including hyphenated ones were utilized for the purpose of quality control of commercial products with many bioactive constituents.

\section{ACKNOWLEDGMENT}

The authors thank Professor Ibrahim Othman, General Director of Atomic Energy Commission of Syria for encouragement and provide technical support.

\section{CONFLICT OF INTEREST}

The authors declare no conflict of interest with the data contained in the manuscript.

\section{REFERENCES}

1. Locatelli C., Melucci D., Locatelli M.: Curr. Bioact. Compd. 10, 181 (2014).

2. Liang Y.Z., Xie P.S., Chan K.: J. Chromatogr. B 812, 53 (2004).

3. Diuzheva A., Locatelli M., Tartaglia A., Goga M., Ferrone V., et al.: Phytochem. Anal. 31, 687 (2020).

4. Melucci D., Locatelli M., De Laurentiis F., Zengin G., Locatelli C.: Lett. Drug Des. Discov. 15, 270 (2018).

5. Yongyu Z., Shujun S., Jianye D., Wenyu W., Huijuan C., et al.: in Quality Control of Herbal Medicines and Related Areas. InTech, Vienna, Austria 2011.

6. Lesley B., Marc C.: Herbs and Natural Supplements, An Evidence-Based Guide. 3 ed., Churchill Livingstone, Australia 2010.

7. Georgiev M.I., Ivanovska N., Alipieva K., Dimitrova P., Verpoorte R.: Phytochemistry 92, 8 (2013).

8. Li M., Hou X.F., Zhang J., Wang S.C., Fu Q., He L.C.: J. Pharm. Anal. 1, 81 (2011).

9. Goel A., Boland C.R., Chauhan D.P.: Cancer Lett. 172, 111 (2001).

10. Azab A., Nassar A., Azab A.N.: Molecules 21, 19 pages (2016).

11. Powanda M.C., Rainsford K.D.: Inflammopharmacology 19, 227 (2010).

12. Sumiwi S. A., Sihombing O. S., Subarnas A., Abdassah M., Levita J.: Int. J. Pharm. Pharm. Sci. 7, 51 (2015).

13. Simon J. E., Chadwick A.F., Craker L.E.: Herbs: An Indexed Bibliography. 1971-1980. 
The Scientific Literature on Selected Herbs, and Aromatic and Medicinal Plants of the Temperate Zone. Archon Books, Hamden, CT 1984.

14. Nowak J., Woźniakiewicz M., Gładysz M., Sowa A., Kościelniak P.: Food Anal. Methods 9, 1246 (2015).

15. Wang W., Sun C., Mao L., Ma P., Liu F., et al.: Trends Food Sci. Technol. 56, 21 (2016).

16. Xiao X., Shi D., Liu L., Wang J., Xie X., et al.: PLoS One 6, e22934 (2011).

17. Sahu R., Saxena J.: J. Pharmacogn. Phytochem. 2, 176 (2013).

18. Uddin Z., Shad A.A., Bakht J., Ullah I., Jan S.: Pak. J. Pharm. Sci. 28, 1699 (2015).

19. Qiao A., Wang Y., Xiang L., Zhang Z., He X.: J. Funct. Foods 13, 308 (2015).

20. Ice C.H., Wender S.H.: J. Am. Chem. Soc. 75, 50 (1953).

21. Kumar V., Singh S., Singh A., Dixit A.K., Srivastava B., et al.: JBAPN 8, 192 (2018).

22. Siddiqui M.Z.: Indian J. Pharm. Sci. 73, 255 (2011).

23. Zargar M., Azizah A.H., Roheeyati A.M., Fatimah A.B., Jahanshiri F., Pak-Dek M.S.: J. Med. Plants Res. 5, 2525 (2011).

24. Nair A., Chattopadhyay D., Saha B.: New Look to Phytomedicine 2019, 435 (2019).

25. Hussain H., Al-Harrasi A., Al-Rawahi A., Hussain J.: Evid. Based Complement. Alternat. Med. 2014, 12 pages (2013).

26. Tilvi S., Parvatkar R.R., Majik M.S.: Stud. Nat. Prod. Chem. 62, 455 (2019).
27. Roy A., Park H.J., Abdul Q.A., Jung H.A., Choi J.S.: Nat. Prod. Sci. 24, 28 (2018).

28. Nogueira M.N.M., Aquino S.G., Rossa Junior C., Spolidorio D.M.P.: Inflamm. Res. 63, 769 (2014).

29. Lee J.H., Kim G.H.: J. Food Sci. 75, H212 (2010).

30. Li H., Pan S., Xu X.: Eur. J. Pharmacol. 856, 172416 (2019).

31. Noreen Y., Serrano G., Perera P., Bohlin L.: Planta Med. 64, 520 (1998).

32. Gyurkovska V., Alipieva K., Maciuk A., Dimitrova P., Ivanovska N., et al.: Food Chem. 125, 171 (2011).

33. Gagliardini E., Benigni A., Perico N: Pharmacological induction of kidney regeneration in: Kidney Transplantation, Bioengineering and Regeneration. Orlando G., Remuzzi G., Williams D.F., Eds., pp. 1025-1037, Academic Press, Cambridge, MA, United States 2017.

34. Srivastava C.: Medicinal Plants - International Journal of Phytomedicines and Related Industries 1, 27 (2009).

35. He M., Min J.W., Kong W.L., He X.H., Li J.X., Peng B.W.: Fitoterapia 115, 74 (2016).

36. Gill B.S., Mehra R., Navgeet., Kumar S.: Mol. Biol. Rep. 45, 2925 (2018).

37. Neog M.K., Joshua Pragasam S., Krishnan M., Rasool M.: Biofactors 43, 698 (2017).

38. Ringbom T., Huss U., Stenholm A., Flock S., Skattebøl L., et al.: J. Nat. Prod. 64, 745 (2001). 